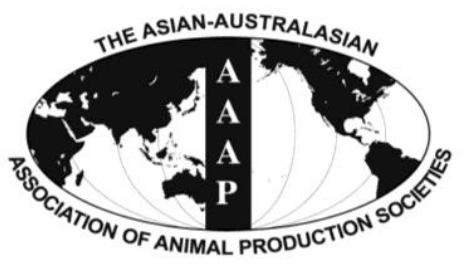

Asian-Aust. J. Anim. Sci.

Vol. 25, No. $8: 1055$ - 1062

August 2012

www.ajas.info

http://dx.doi.org/10.5713/ajas.2012.12029

\title{
Effects of Growth Hormone Gene Polymorphism on Lipogenic Gene Expression Levels in Diaphragm Tissues of Japanese Black Heifers
}

\author{
Astrid Ardiyanti, Tsuyoshi Abe ${ }^{1}$, Nanae Tameoka ${ }^{1}$, Eiji Kobayashi ${ }^{1}$, Noriaki Shojii ${ }^{2}$, \\ Yoshihisa Ohtani, Keiichi Suzuki ${ }^{3}$, Sang-gun Roh and Kazuo Katoh* \\ Department of Animal Physiology, Graduate School of Agricultural Science, \\ Tohoku University, Sendai 981-8555, Japan
}

\begin{abstract}
Two SNPs, i.e. L127V and T172M, of bovine growth hormone (GH) causing the presence of GH gene haplotypes A, B, and $\mathrm{C}$ was previously shown to alter intramuscular fatty acid (FA) composition in Japanese Black (JB) heifers. To determine the SNP effect on somatotropic hormone concentration and lipogenesis, we measured plasma GH, insulin, and insulin-like growth factor-1 (IGF-1) concentrations. We also measured mRNA levels of fatty acid synthase (FASN), stearoyl-coA desaturase (SCD), and sterol regulatory element binding proteins-1 (SREBP-1) and FA composition in diaphragm tissues. Heifers with genotype CC had the lowest plasma insulin concentration and FASN and SCD mRNA levels among genotypes. FASN mRNA levels in haplotype A tended to positively correlate with saturated FA (SFA) content and negatively correlated with C18:2 and unsaturated FA (USFA) contents. SCD mRNA levels in haplotype A positively correlated with monounsaturated FA (MUFA) contents and negatively correlated with C18:0 content. They also tended to positively correlate with C16:1, C18:1, and USFA contents and USFA/SFA ratio and negatively correlate with SFA content. Taken together, GH gene polymorphism affects the lipogenic genes expression levels and their relationships with fatty acid compositions in diaphragm tissues of JB heifers at 31 months of age. (Key Words: Japanese Black Heifers, GH Gene Polymorphism, Fatty Acid Synthase, Stearoyl-coA Desaturase, Sterol Regulatory Element Binding Proteins-1, Gene Expression Levels)
\end{abstract}

\section{INTRODUCTION}

Japanese Black (JB) cattle are known for their highly marbled beef, greater content of unsaturated fatty acids (USFA), and lower melting point of fat compared to other breeds (Smith et al., 2006). In this breed, single-nucleotide polymorphisms (SNPs) in exon 5 of the GH gene have been reported to cause the amino acid substitution from CTG (leucine; Leu) to GTG (valine; Val) and from ACG (threonine; Thr) to ATG (methionine; Met) at codon 127 and 172, respectively. Moreover, there are 3 haplotypes observed in these codons, namely haplotype A (Leu-Thr),

\footnotetext{
* Corresponding Author: Kazuo Katoh. Tel: +81-22-7178700, Fax: +81-22-7178701, E-mail: kato@bios.tohoku.ac.jp

${ }^{1}$ National Livestock Breeding Center, Fukushima 961-8511, Japan.

2 Yamagata General Agricultural Research Center, Shinjo 9960041, Japan.

${ }^{3}$ Department of Animal Breeding and Genetics, Graduate School of Agricultural Science, Tohoku University, Sendai 981-8555, Japan.

Submitted Jan. 13, 2012; Accepted Apr. 4, 2012; Revised May 1, 2012
}

haplotype $\mathrm{B}$ (Val-Thr), and haplotype $\mathrm{C}$ (Val-Met) resulting in 6 genotypes, i.e., $\mathrm{AA}, \mathrm{AB}, \mathrm{BB}, \mathrm{AC}, \mathrm{BC}$, and $\mathrm{CC}$ (Chikuni et al., 1997). Our previous studies (Katoh et al., 2008; Ardiyanti et al., 2009a; Ardiyanti et al., 2009b) have demonstrated that this polymorphism was related to characteristics in beef quality, carcass weights, and plasma hormone concentrations in JB cattle. Regarding i.m. fatty acid (FA) composition, JB cattle with haplotype A had greater carcass weight yet lower USFA contents, whereas those with haplotype $\mathrm{C}$ had lower carcass weight yet greater USFA contents.

Our present study was focused to analyze fatty acid synthesis in cattle with GH haplotypes A, B, and C. Three main enzymes that are involved in biosynthesis of lipid, i.e. fatty acid synthase (FASN), stearoyl-coA desaturase (SCD), and sterol regulatory element binding proteins-1 (SREBP-1), were selected for gene expression analysis. FASN and SCD are known for their roles in synthesizing saturated and unsaturated fatty acids, respectively (Ntambi, 1995; Chirala and Wakil, 2004). These genes are activated by SREBPs that bind to the sterol regulatory element sequences at their promoter regions (Shimano, 2001). A study using pig 
adipocytes has shown that GH decreases FASN mRNA level through reduction of FASN gene transcription and FASN mRNA stability. Previous reports on Holstein cows showed that GH reduces SCD mRNA levels in adipose tissue (Beswick and Kennelly, 2000). Insulin, on the other hand, is known to have stimulatory effects on SREBP-1, FASN, and SCD gene expression in adipose tissues (Yin et al., 1998; Shimano, 2001; Daniel et al., 2004).

Therefore, we aimed to determine if bovine $\mathrm{GH}$ gene polymorphism affects the lipogenesis regulation in 31month old heifers by altering the lipogenic gene expressions.

\section{MATERIALS AND METHODS}

\section{Animals}

JB heifers ( $\mathrm{n}=111 ; 30.9 \pm 0.9$ months of age) raised under the same housing and feeding condition in Yamagata prefecture, Japan were used in this study. For hormones and lipogenic genes expression studies, heifers were grouped based on their $\mathrm{GH}$ genotypes, i.e. $\mathrm{AA}, \mathrm{AB}, \mathrm{BB}, \mathrm{AC}, \mathrm{BC}$, and CC. For Pearson's correlation study, the heifers were divided into three haplotype groups according to presence of the related haplotypes, i.e., group haplotype A, B, or C.

\section{Blood plasma and diaphragm tissues collection}

Approximately $50 \mathrm{ml}$ of whole blood sampled before slaughter was centrifuged at $2,000 \times g$ for $15 \mathrm{~min}$ at $4^{\circ} \mathrm{C}$ for plasma collection. Then, $200 \mathrm{U}$ of heparin and 1 unit of trypsin inhibitor (Roche Applied Science, Indianapolis, USA) were added and the plasma was kept frozen at $-30^{\circ} \mathrm{C}$ until analysis. For genomic DNA and total RNA isolation, diaphragm tissues were collected immediately after sacrifice, placed in RNase free vials, and kept frozen in liquid nitrogen before storage at $-80^{\circ} \mathrm{C}$.

\section{Genomic DNA isolation and GH genotyping}

Genomic DNA was isolated from approximately $50 \mathrm{mg}$ of homogenized bovine diaphragm tissue using the QuickGene-800 automatic nucleic acid isolation system (Fujifilm, Tokyo, Japan). The eluted DNA concentration was measured using Nanodrop ${ }^{\circledR}$ ND-1000 Spectrophotometer (Thermo Fisher Scientific, Wilmington, DE, USA). The GH genotype was determined by allelespecific multiplex (ASM)-PCR according to the method of Chikuni et al. (1997) with a slight modification. ASM-PCR was carried out in $15-\mu l$ reaction mixtures containing 150 ng of template DNA, $10 \mathrm{mM}$ Tris $\mathrm{HCl}(\mathrm{pH} \mathrm{8.3),} 50 \mathrm{mM}$ $\mathrm{KCl}, 1.5 \mathrm{mM} \mathrm{MgCl}, 200 \mu \mathrm{M}$ each of dNTPs, 0.5 units of AmpliTaq Gold DNA polymerase (Applied Biosystems, Foster City, CA, USA), 10 pmol each of common primers GH4F and GH5R, and 5 pmol and 3 pmol of specific primers GHAR and GHABR (Sigma Genosys, Ishikari, Japan), respectively. The reverse primer GHAR, GHABR, and GH5R were designed to determine the GH haplotype A, $\mathrm{B}$, and $\mathrm{C}$, respectively. The sequences of primers are described in Table 1. Template DNA was amplified using a PC808 thermal cycler (Astec, Fukuoka, Japan) as follows: a primary cycle of denaturation $\left(94^{\circ} \mathrm{C}\right.$ for $\left.9 \mathrm{~min}\right), 38$ cycles of denaturation $\left(94^{\circ} \mathrm{C}\right.$ for $\left.30 \mathrm{~s}\right)$, annealing $\left(55^{\circ} \mathrm{C}\right.$ for $\left.20 \mathrm{~s}\right)$, and extension $\left(72^{\circ} \mathrm{C}\right.$ for $\left.15 \mathrm{~s}\right)$, followed by one cycle of final extension $\left(72^{\circ} \mathrm{C}\right.$ for $\left.7 \mathrm{~min}\right)$. The PCR products were then analyzed by horizontal electrophoresis (100 V for $35 \mathrm{~min}$ ) through 2\% agarose gel (Invitrogen, Carlsbad, CA, USA), ethidium bromide staining $(0.5 \mu \mathrm{g} / \mathrm{ml})$ for $40 \mathrm{~min}$, and visualization by UV fluorescence using the Chemiimager digital imaging system (Alpha Innotech Corporation, San Diego, CA, USA). Single 347, 483, and 656-bp fragments were produced in $\mathrm{GH}$ genotypes $\mathrm{AA}, \mathrm{BB}$, and $\mathrm{CC}$, respectively, whereas the combinations of two fragments with different sizes were produced in $\mathrm{GH}$ genotypes $\mathrm{AB}$, $\mathrm{AC}$, and $\mathrm{BC}$.

\section{Total RNA isolation and cDNA synthesis}

Total RNA was isolated from approximately $100 \mathrm{mg}$ of homogenized bovine diaphragm tissue using $1 \mathrm{ml}$ of ISOGEN (Nippon Gene, Toyama, Japan). Before proceeding to cDNA synthesis, $5 \mu \mathrm{g}$ of total RNA was incubated at $65^{\circ} \mathrm{C}$ for $10 \mathrm{~min}$ with DNase I (Invitrogen, Carlsbad, CA, USA). The DNase treated total RNA $(0.5 \mu \mathrm{g})$ was then subjected to reverse transcriptase (RT) PCR for cDNA synthesis using High Capacity RNA-to-cDNA Master Mix (Applied Biosystem, Foster City, CA, USA) contaning both random primers and oligo(dT) primer. The RT-PCR was carried out in 96-well GeneAmp ${ }^{\circledR}$ PCR System 9700 (Applied Biosystem, Foster City, CA, USA) with condition as follows: $25^{\circ} \mathrm{C}$ for $5 \mathrm{~min}, 42^{\circ} \mathrm{C}$ for $30 \mathrm{~min}$, and $85^{\circ} \mathrm{C}$ for $5 \mathrm{~min}$.

\section{Real-time PCR}

Real-time PCR was conducted using Power SYBR ${ }^{\circledR}$

Table 1. Primer sequences for determining bovine GH genotype using ASM-PCR (Chikuni et al., 1997)

\begin{tabular}{lll}
\hline Name & Direction & Sequence $\left(5^{\prime} \rightarrow 3^{\prime}\right)$ \\
\hline GH4F & Forward & TCTATGAGAAGCTGAAGGACCTGGAGGAA \\
GHAR & Reverse & CGGGGGGTGCCATCTTCCAG \\
GHABR & Reverse & ATGACCCTCAGGTACGTCTCCG \\
GH5R & Reverse & CCAGAATAGAATGACACCTACTCAGACAAT \\
\hline
\end{tabular}


Table 2. Primers sequences for measuring lipogenic gene expression levels using real-time PCR

\begin{tabular}{lll}
\hline Name & Direction & \multicolumn{1}{c}{ Sequence $\left(5^{\prime} \rightarrow 3^{\prime}\right)$} \\
\hline FASN & Forward & GACGGCTCGCACACCTTC \\
& Reverse & AGGGCCTCCAGCACTCTAC \\
SCD $^{1}$ & Forward & GTGATGTTCCAGAGGAGGTACTACAA \\
& Reverse & AACGTTTCATCCCACAGATACCA \\
SREBP-1 & Forward & CGAGCTTCGTGGTTTCCAGAG \\
& Reverse & ATCAGTCGGGCAGTGGCTTC \\
\hline
\end{tabular}

${ }^{1}$ Taniguchi et al., 2004.

Green PCR Master Mix (Applied Biosystem, Foster City, CA, USA) and 7500 Real-Time PCR System (Applied Biosystem, Foster City, CA, USA). Sequence of primers for FASN, SCD, and SREBP-1 genes is listed in Table 2. Also, GAPDH (Taqman MGB P/N 4324034, Applied Biosystem) was used as the housekeeping gene to normalize the FASN, SCD, and SREBP-1 mRNA levels. The real-time PCR condition was performed with initial denaturation at $50^{\circ} \mathrm{C}$ for $2 \mathrm{~min}$ and $95^{\circ} \mathrm{C}$ for $10 \mathrm{~min}$ and 55 cycles of amplification at $95^{\circ} \mathrm{C}$ for $15 \mathrm{~s}$ and $60^{\circ} \mathrm{C}$ for $1 \mathrm{~min}$. To analyze the differences of FASN, SCD, and SREBP-1 mRNA levels among genotypes and their correlations with fatty acid compositions, $2^{-\Delta \Delta} \mathrm{Ct}$ and $2^{-\Delta} \mathrm{Ct}$ were used, respectively.

\section{Measurements of plasma GH, IGF-I, and insulin concentrations}

The double-antibody RIA method was performed to measure GH and IGF-I concentrations, whereas insulin concentrations were measured using the single-antibody RIA method, as previously described by (Kuhara et al., 1991). Intra-assay coefficients and minimum detectable concentrations for GH, IGF-I, and insulin were $4.26 \%$ and $0.0603 \mathrm{ng} / \mathrm{ml} ; 9.21 \%$ and $50 \mathrm{pg} / \mathrm{ml}$; and $24.67 \%$ and 0.1008 $\mu \mathrm{U} / \mathrm{ml}$, respectively.

\section{Gas chromatography}

Ten milliliters of chloroform and methanol solution (2:1 $\mathrm{v} / \mathrm{v}$ ) was added to diaphragm tissues. The chloroform and methanol fractions were then separated by adding diluted sulphuric acid. Using rotary evaporator, the chloroform fraction was dried up at $60^{\circ} \mathrm{C}$ and the isolated lipid was diluted using hexane. Then, $0.5 \mathrm{~N}$ sodium methoxidemethanol was added to the mixture and the mixture was incubated at $80^{\circ} \mathrm{C}$ for 20 min for methyl esterification. The mixture was diluted with hexane and water and subjected to gas chromatography. The methylated lipid was analyzed using a gas chromatography (Hitachi G-3000, Tokyo, Japan) equipped with a $1.5 \mathrm{~m} \times 3 \mathrm{~mm}$ glass column (Unisole3000; GL Science Inc., Tokyo, Japan). The carrier gas was nitrogen and the column oven condition was programmed from an initial temperature of $205^{\circ} \mathrm{C}$ to a final temperature of $222^{\circ} \mathrm{C}$ at the rate of $1^{\circ} \mathrm{C} / \mathrm{min}$ with the column head pressurized at $1.0 \mathrm{~kg} / \mathrm{cm}^{2}$. Identification of fatty acids (myristic acid, C14:0; palmitic acid, C16:0; palmitoleic acid, C16:1; stearic acid, C18:0; oleic acid, C18:1; linoleic acid, C18:2) was achieved by comparing the relative retention time of fatty acid peaks from samples with those of standards. The amount of fatty acid contents was determined using its area percentage.

\section{Statistical analysis}

All data for hormone and gene expression measurements in genotype groups were expressed as the mean \pm SE. Duncan`s multiple range test was used to analyze the difference among genotype groups after one-way ANOVA (Excel Toukei, add-in software for MS- Excel, ESUMI Co., Ltd.). To analyze correlations between gene expression and fatty acid composition, Pearson's correlation coefficient between two variables was used. Differences were considered significant at $\mathrm{p}<0.05$ and differences at $\mathrm{p}<0.10$ were considered as tendencies.

\section{RESULTS}

\section{Plasma GH, IGF-I, and insulin concentrations}

To observe the SNP effects on concentrations of hormones involved in somatotropic axis, we measured the plasma concentrations of GH, IGF-1, and insulin in heifers with different $\mathrm{GH}$ genotypes. As shown in Figure 1A and 1B, GH genotypes did not significantly alter plasma $\mathrm{GH}$ and IGF-1 concentrations $(\mathrm{p}=0.25$ and $\mathrm{p}=0.18$, respectively). However, for insulin concentrations, heifers with genotype $\mathrm{CC}$ had the lowest concentrations among all genotypes (Figure 1C; $\mathrm{p}=0.02$ ).

\section{Genes expression levels of FASN, SCD, and SREBP-1}

Next, we examined the SNP effects on gene expression levels of FASN, SCD, and SREBP-1 in diaphragm tissues. As demonstrated in Figure 2A and 2B, the expression levels of FASN and SCD genes in heifers with genotype CC tended to be the lowest among genotypes $(\mathrm{p}=0.06$ and $\mathrm{p}=$ 0.07 , respectively) being approximately $50 \%$ lower than those in genotype AA. The lowest SREBP-1 mRNA level 


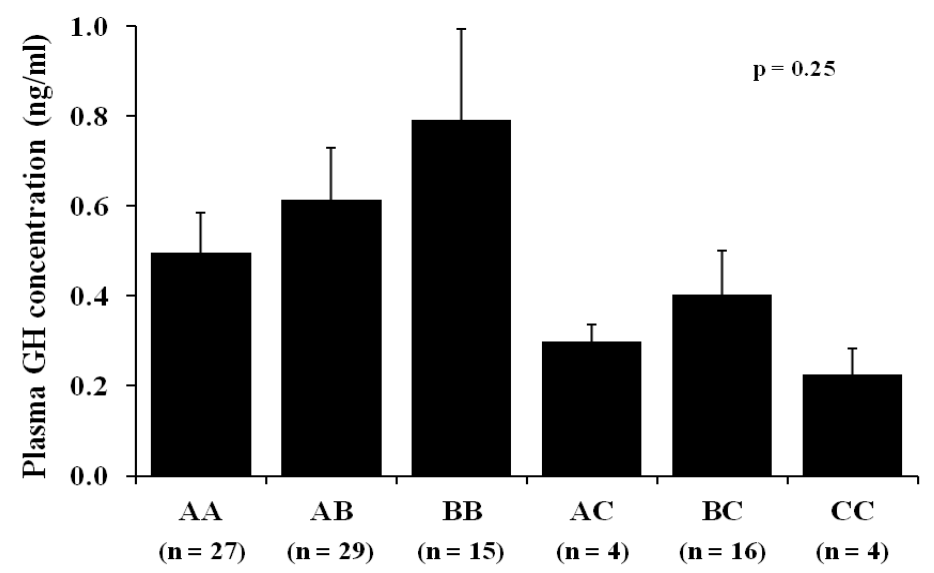

GH genotype

(animal number)

(A)

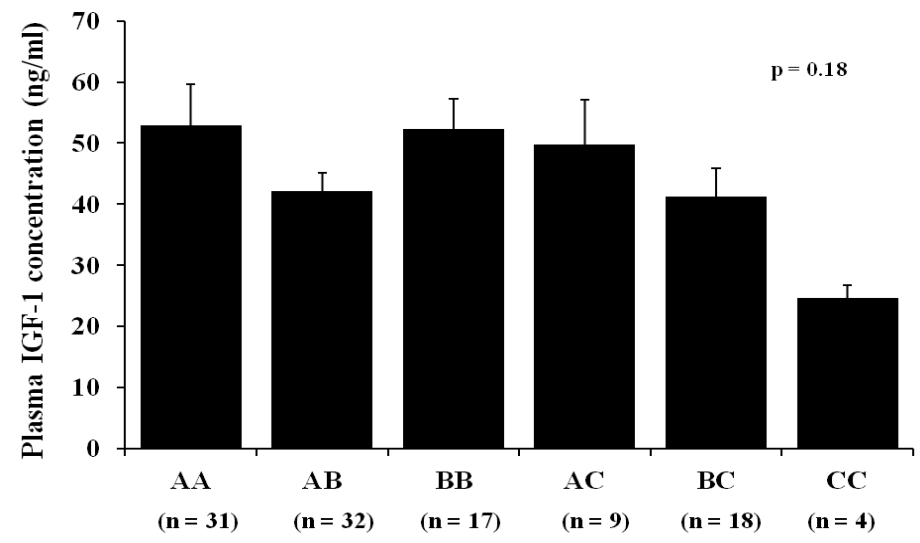

GH genotype

(animal number)

(B)

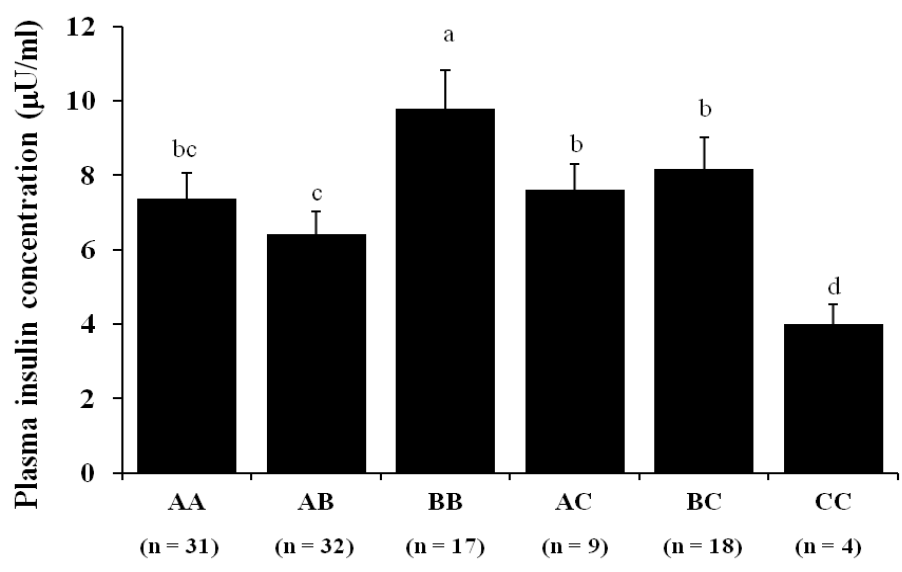

GH genotype

(animal number)

(C)

Figure 1. Plasma concentrations of (A) GH, (B) IGF-I, and (C) insulin in 31-mo-old Japanese Black heifers with GH genotypes AA, AB, $\mathrm{BB}, \mathrm{AC}, \mathrm{BC}$, and CC. Values are mean \pm SE. ${ }^{\mathrm{a}, \mathrm{b}, \mathrm{c}, \mathrm{d}}$ Means with different superscripts differ $(\mathrm{p}<0.05)$. 


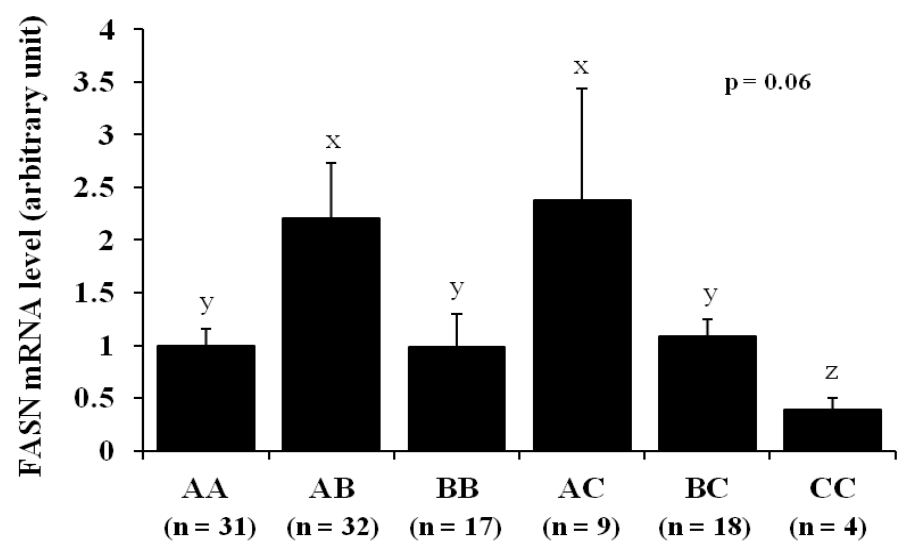

GH genotype

(animal number)

(A)

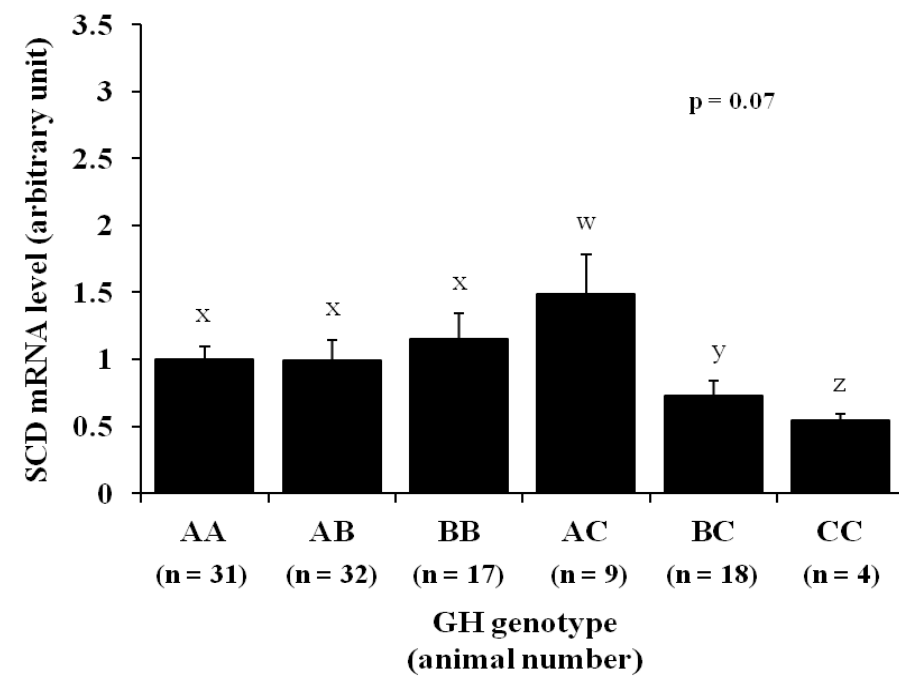

(B)

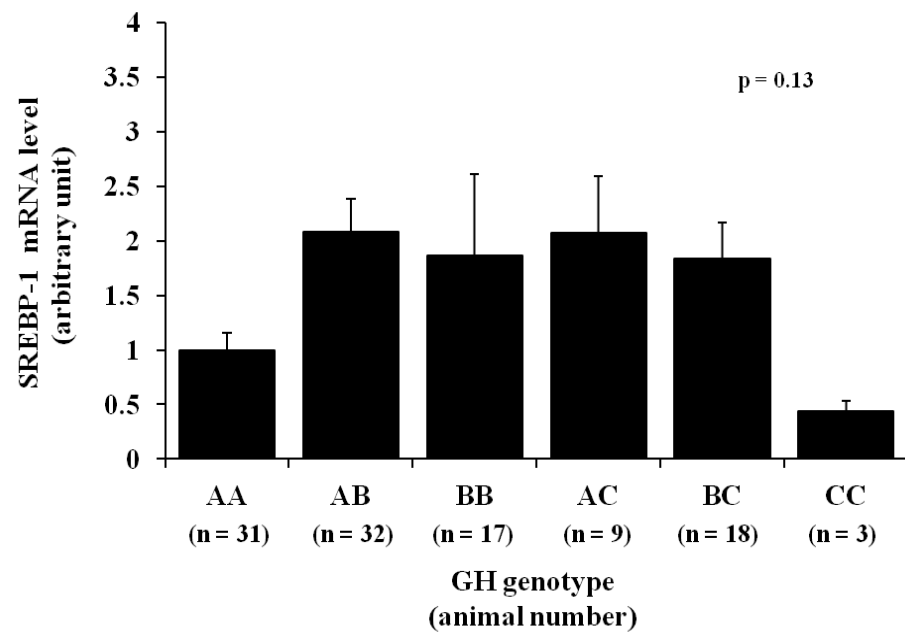

(C)

Figure 2. Genes expression levels of (A) FASN, (B) SCD, and (C) SREBP-1 in diaphragm tissues of 31-mo-old Japanese Black heifers with $\mathrm{GH}$ genotypes $\mathrm{AA}, \mathrm{AB}, \mathrm{BB}, \mathrm{AC}, \mathrm{BC}$, and $\mathrm{CC}$. Values are mean $\pm \mathrm{SE}$. ${ }^{\mathrm{w}, \mathrm{x}, \mathrm{y}, \mathrm{z}}$ Means with different superscripts tended to differ $(\mathrm{p}<0.10)$. 
was also observed in heifers with genotype $\mathrm{CC}$, although the difference was not statistically significant (Figure $2 \mathrm{C} ; \mathrm{p}$ $=0.13$ ).

Correlations between lipogenic genes expressions levels and i.m. fatty acid compositions

Using the same Pearson's analysis, we examined if the haplotype differences affect the relationships between the lipogenic gene expression levels and i.m. fatty acid composition in diaphragm tissues (Table 3). However, due to a small population number of heifers with genotype CC (only 4 heifers out of 111 heifers), we grouped the heifers

Table 3. Pearson's correlation coefficient among FASN, SCD, and SREBP-1 mRNA levels and fatty acid composition in diaphragm tissues of heifers with GH haplotype A $(n=72), B(n=$ $67)$, and $\mathrm{C}(\mathrm{n}=30)$

\begin{tabular}{|c|c|c|c|c|}
\hline \multirow{2}{*}{$\begin{array}{l}\text { mRNA } \\
\text { level }\end{array}$} & \multirow{2}{*}{$\begin{array}{l}\text { Fatty acid } \\
\text { composition }\end{array}$} & \multicolumn{3}{|c|}{ R-values in each GH haplotype } \\
\hline & & $\begin{array}{c}\text { Haplotype } \\
A^{1}\end{array}$ & $\begin{array}{l}\text { Haplotype } \\
\mathrm{B}^{2}\end{array}$ & $\begin{array}{c}\text { Haplotype } \\
\mathrm{C}^{3}\end{array}$ \\
\hline \multirow[t]{9}{*}{ FASN } & C16:0 (\%) & 0.19 & $0.21 *$ & 0.01 \\
\hline & C18:0 (\%) & 0.13 & 0.09 & -0.02 \\
\hline & $\mathrm{C} 16: 1(\%)$ & -0.04 & 0.05 & 0.11 \\
\hline & $\mathrm{C} 18: 1(\%)$ & -0.19 & -0.19 & -0.01 \\
\hline & $\mathrm{C} 18: 2(\%)$ & $-0.21 *$ & $-0.27 * *$ & 0.05 \\
\hline & SFA $(\%)$ & $0.20 *$ & 0.17 & 0.00 \\
\hline & MUFA (\%) & -0.19 & -0.17 & 0.02 \\
\hline & USFA $(\%)$ & $-0.20 *$ & -0.18 & 0.02 \\
\hline & USFA/SFA & -0.17 & -0.16 & 0.01 \\
\hline \multirow[t]{9}{*}{ SCD } & C16:0 (\%) & -0.12 & -0.05 & -0.13 \\
\hline & $\mathrm{C} 18: 0(\%)$ & $-0.26 * *$ & -0.19 & -0.16 \\
\hline & $\mathrm{C} 16: 1(\%)$ & $0.22 *$ & 0.16 & 0.24 \\
\hline & C18:1 (\%) & $0.21 *$ & 0.12 & 0.16 \\
\hline & $\mathrm{C} 18: 2(\%)$ & -0.17 & -0.12 & 0.00 \\
\hline & SFA $(\%)$ & $-0.22 *$ & -0.13 & -0.15 \\
\hline & MUFA (\%) & $0.24 * *$ & 0.14 & 0.19 \\
\hline & USFA $(\%)$ & $0.23 *$ & 0.12 & 0.19 \\
\hline & USFA/SFA & $0.23 *$ & 0.13 & 0.19 \\
\hline \multirow[t]{9}{*}{ SREBP-1 } & C16:0 (\%) & -0.09 & -0.01 & -0.05 \\
\hline & C18:0 (\%) & 0.07 & -0.07 & 0.16 \\
\hline & C16:1 (\%) & -0.09 & 0.10 & -0.23 \\
\hline & C18:1 (\%) & -0.03 & 0.06 & -0.05 \\
\hline & C18:2 (\%) & 0.03 & -0.09 & 0.13 \\
\hline & SFA $(\%)$ & 0.07 & -0.05 & 0.08 \\
\hline & MUFA (\%) & -0.05 & 0.07 & -0.10 \\
\hline & USFA $(\%)$ & -0.05 & 0.07 & -0.09 \\
\hline & USFA/SFA & -0.04 & 0.04 & -0.09 \\
\hline
\end{tabular}

$* \mathrm{p}<0.10 ; * * \mathrm{p}<0.05$.

${ }^{1} \mathrm{GH}$ genotype $\mathrm{AA}, \mathrm{AB}$, and $\mathrm{AC} .{ }^{2} \mathrm{GH}$ genotypes $\mathrm{AB}, \mathrm{BB}$, and $\mathrm{BC}$.

${ }^{3} \mathrm{GH}$ genotypes $\mathrm{AC}, \mathrm{BC}$, and $\mathrm{CC}$.

FASN = Fatty acid synthase SCD = Stearoyl-coA desaturase SREBP-1 = Sterol regulatory element binding proteins-1; GH = Growth hormone; SFA = Saturated fatty acids; MUFA = Monounsaturated fatty acids; USFA = Unsaturated fatty acids into group haplotype $\mathrm{A}$, i.e. those with genotype $\mathrm{AA}, \mathrm{AB}$, and $\mathrm{AC}$; haplotype $\mathrm{B}$, i.e. genotype $\mathrm{BB}, \mathrm{AB}$, and $\mathrm{BC}$; and haplotype $\mathrm{C}$, i.e. genotype $\mathrm{CC}, \mathrm{AC}$, and $\mathrm{BC}$. Although only at tendency levels, FASN mRNA levels in haplotype A positively correlated with SFA contents and negatively correlated with C18:2 and USFA contents. FASN mRNA level in haplotype B correlated with $\mathrm{C} 16: 0$ content at tendency level and with C18:2 contents. However, FASN mRNA level in haplotype $\mathrm{C}$ did not show any correlations with the FA compositions. Moreover, SCD mRNA levels in haplotype A positively correlated with MUFA contents and negatively correlated with $\mathrm{C} 18: 0$ content $(\mathrm{p}<0.05)$. The SCD mRNA levels in haplotype A also tended to positively correlate with $\mathrm{C} 16: 1, \mathrm{C} 18: 1$, and USFA contents and USFA/SFA ratio while negatively correlate with SFA content $(\mathrm{p}<0.10)$. SCD mRNA levels in haplotypes B and C, however, did not correlate with any of the FA compositions. As for SREBP-1, there was no correlation found between SREBP-1 mRNA levels and the FA compositions regardless of the haplotypes.

\section{DISCUSSION}

Based on our previous studies (Ardiyanti et al., 2009a; Ardiyanti et al., 2009b) on GH gene polymorphism in JB cattle, our present study addressed the GH SNP effects on somatotropic hormone concentrations and lipogenesis in JB heifers. We previously have demonstrated that 10 mo-old heifers with genotype $\mathrm{AC}, \mathrm{BC}$, and $\mathrm{CC}$ had significantly greater plasma $\mathrm{GH}$ concentrations than those with other genotypes (Ardiyanti et al., 2009a). This result led us to speculate that the SNP might alter GH-GHR binding efficiency followed by a GH resistance condition and hence increased GH release. However, in our present study, basal GH and IGF-I concentrations did not significantly differ among GH genotypes. It is possible that the absence of the SNP effects on GH concentrations in the present study was due to animal age difference. Heifers used in this study were 31 months of age, during which $\mathrm{GH}$ concentrations were probably already declining and thus dampening $\mathrm{GH}$ gene polymorphism effects. Subsequently, it was not surprising when the plasma IGF-1 was found at statistically same concentrations among genotypes. However, it is noteworthy that we only did a single measurement for the plasma GH concentration, which probably could not represent the overall effect of the SNP on the pulsatile release of $\mathrm{GH}$. Plasma insulin was found at the lowest concentrations in animals with genotype $\mathrm{CC}$ and this result was in accordance with our previous results (Ardiyanti et al., 2009a). GH excess is known to impair cell sensitivity to insulin resulting in insulin resistance. Moreover, GH administration has been linked to increased insulin release from the pancreas through STAT5A signaling (Etherton and 
Bauman, 1998; Dominici et al., 2005; Feng et al., 2009).

In regards to lipogenic gene expressions, it is surprising that despite the lower SFA and the greater USFA contents shown by cattle with genotype CC in previous studies, our present results revealed that FASN and SCD mRNA levels in heifers with genotype CC were in fact the lowest among genotypes. However, SREBP-1 mRNA level was not affected by the genotype difference indicating that the SNP's effects on FASN and SCD mRNA levels might be independent from SREBP-1. Also, given that the promoter regions of FASN and SCD genes are activated by insulin (Latasa et al., 2000; Keating et al., 2006), the low level of insulin concentration in heifers with genotype CC might relate to their low FASN and SCD mRNA levels as well.

As reviewed in another study (Shimano, 2001), FASN and SCD genes are among other genes activated by SREBP-1 and therefore it is very likely that FASN and SCD mRNA levels would be simultaneously activated. Our correlation analysis has indeed demonstrated strong positive correlations among FASN, SCD and SREBP-1 mRNA, however, the haplotype differences did not seem to alter the correlations, except for haplotype B where FASN mRNA level did not correlate with SREBP-1 mRNA level (data not shown). This result suggests that the GH SNP alters the FASN and SCD expression levels without involving SREBP-1.

Our analysis of the FA compositions, however, has shown interesting results where the correlations between FASN and SCD mRNA levels with the FA contents were more pronounced in group haplotype A than in haplotypes $\mathrm{B}$ and C. FASN and SCD are known for their roles in synthesizing saturated and unsaturated fatty acids, respectively (Ntambi, 1995; Chirala and Wakil, 2004). This is accordingly reflected in group haplotype A through the positive correlations between FASN mRNA levels and SFA contents and the negative correlations between SCD mRNA levels and USFA contents. In contrast, there was no correlation between the gene expression levels and FA compositions observed in haplotype $\mathrm{C}$. Moreover, the only correlations shown in haplotype B were between FASN mRNA levels and C16:0 and C18:2 contents. These results implied that the GH SNP has not only altered the gene expression levels of FASN and SCD, but also the relationships between the gene expressions of those enzymes and their FA products.

$\mathrm{GH}$ treatment has been previously shown to reduce SCD gene expression to undetectable levels in bovine adipose tissues and this was considered to be the direct effect of GH on SCD (Beswick and Kennelly, 2000). In different studies, $\mathrm{GH}$ has also been shown to negate the insulin effect to induce FASN and SCD transcriptions in rats and pigs (Yin et al., 1998). Moreover, STAT5A also has been shown to directly repress FASN mRNA levels in 3T3-
L1 cells (Hogan and Stephens, 2005). We have speculated on the hypothetical alteration of GH-GHR binding efficiency in $\mathrm{GH}$ haplotype $\mathrm{C}$ that might lessen the repression effect by STAT5 on promoter regions of FASN and SCD genes. However, our present study has shown conflicting results where the mRNA levels of both enzymes were lower in genotype $\mathrm{CC}$, although this might be attributed to the low insulin concentrations and tissue differences. On the other hand, SREBP-1 mRNA in porcine adipocyte was shown to be unaffected by GH or insulin or both treatment (Louveau and Gondret, 2004). These studies might support our result where GH haplotype difference did not affect the SREBP mRNA levels or its relationship with any of the FA contents either. Therefore, we propose that the alteration of FASN and SCD mRNA levels and FA synthesis by the SNP in GH gene involves direct action of insulin and is independent from SREBP-1.

In our present study, we demonstrated the effects of $\mathrm{GH}$ gene polymorphism on lipogenic genes expression levels in diaphragm tissues of JB heifers at 31 months of age. The variation of GH haplotypes altered the regulation of FASN and SCD gene expressions and fatty acid synthesis in the tissues as well. However, it is a limitation in our study that we measured the lipogenic gene expression levels in diaphragm tissues instead of adipose tissues, which is the main lipogenesis site in ruminants. The haplotype grouping method we used based on the presence of haplotype A, B, and $\mathrm{C}$ due to the small number of heifers with genotype $\mathrm{CC}$ is also another weakness that might interfere with the relationship of the gene expressions with FA compositions. Therefore, further studies are required to elucidate the detailed mechanism on how the GH gene polymorphism affects the lipogenesis mechanism in cattle.

\section{ACKNOWLEDGEMENTS}

The project was partially funded by Research and Development Projects for Application in Promoting New Policy of Agriculture, Forestry, and Fisheries of Japan. This research was conducted at Department of Animal Physiology, Graduate School of Agricultural Science, Tohoku University, Tsutsumidori Amamiyamachi, Aoba, Sendai 981-8555, Japan.

\section{REFERENCES}

Ardiyanti, A., F. Abe, H. Kobashikawa, T. Hirayama, T. Sugino, K. Suzuki and K. Katoh. 2009a. Plasma hormone and metabolite concentrations involved in the somatotropic axis of Japanese Black heifers in association with growth hormone gene polymorphism. Domest. Anim. Endocrinol. 37:243-249.

Ardiyanti, A., Y. Oki, Y. Suda, K. Suzuki, K. Chikuni, Y. Obara and K. Katoh. 2009b. Effects of GH gene polymorphism and sex on carcass traits and fatty acid compositions in Japanese 
Black cattle. Anim. Sci. J. 80:62-69.

Beswick, N. S. and J. J. Kennelly. 2000. Influence of bovine growth hormone and growth hormone-releasing factor on messenger RNA abundance of lipoprotein lipase and stearoylCoA desaturase in the bovine mammary gland and adipose tissue. J. Anim. Sci. 78:412-419.

Chikuni, K., R. Tanabe, S. Muroya, Y. Fukumoto and S. Ozawa. 1997. A simple method for genotyping the bovine growth hormone gene. Anim. Genet. 28:230-232.

Chirala, S. and S. Wakil. 2004. Structure and function of animal fatty acid synthase. Lipids 39:1045-1053.

Daniel, Z. C. T. R., S. E. Richards, A. M. Salter and P. J. Buttery. 2004. Insulin and dexamethasone regulate stearoyl-CoA desaturase mRNA levels and fatty acid synthesis in ovine adipose tissue explants. J. Anim. Sci. 82:231-237.

Dominici, F. P., D. P. Argentino, M. C. Muñoz, J. G. Miquet, A. I. Sotelo and D. Turyn. 2005. Influence of the crosstalk between growth hormone and insulin signalling on the modulation of insulin sensitivity. Growth Horm. IGF Res. 15:324-336.

Etherton, T. D. and D. E. Bauman. 1998. Biology of somatotropin in growth and lactation of domestic animals. Physiol. Rev. 78:745-761.

Feng, J., Z. Gu, M. Wu, F. C. Gwazdauskas and H. Jiang. 2009. Growth hormone stimulation of serum insulin concentration in cattle: Nutritional dependency and potential mechanisms. Domest. Anim. Endocrinol. 37:84-92.

Hogan, J. C. and J. M. Stephens. 2005. The regulation of fatty acid synthase by STAT5A. Diabetes 54:1968-1975.

Katoh, K., S. Kouno, A. Okazaki, K. Suzuki and Y. Obara. 2008. Interaction of $\mathrm{GH}$ polymorphism with body weight and endocrine functions in JB calves. Domest. Anim. Endocrinol. $34: 25-30$.
Keating, A. F., J. J. Kennelly and F. Q. Zhao. 2006. Characterization and regulation of the bovine stearoyl-CoA desaturase gene promoter. Biochem. Biophys. Res. Commun. 344:233-240

Kuhara, T., S. Ikeda, A. Ohneda and Y. Sasaki. 1991. Effects of intravenous infusion of 17 amino acids on the secretion of GH, glucagon, and insulin in sheep. Am. J. Physiol. 260:E21-E26.

Latasa, M. J., Y. S. Moon, K. H. Kim and H. S. Sul. 2000. Nutritional regulation of the fatty acid synthase promoter in vivo: Sterol regulatory element binding protein functions through an upstream region containing a sterol regulatory element. Proc. Natl. Acad. Sci. USA. 97:10619-10624.

Louveau, I. and F. Gondret. 2004. GH and insulin affect fatty acid synthase activity in isolated porcine adipocytes in culture without any modifications of sterol regulatory element binding protein-1 expression. J. Endocrinol. 181:271-280.

Ntambi, J. M. 1995. The regulation of stearoyl-CoA desaturase (SCD). Prog. Lipid Res. 34:39-50.

Shimano, H. 2001. Sterol regulatory element-binding proteins (SREBPs): transcriptional regulators of lipid synthetic genes. Prog. Lipid Res. 40:439-452.

Smith, S. B., D. K Lunt, K. Y. Chung, C. B. Choi, R. K. Tume and M. Zembayashi. 2006. Adiposity, fatty acid composition, and delta-9 desaturase activity during growth in beef cattle. Anim. Sci. J. 77:478-486.

Taniguchi, M., T. Utsugi, K. Oyama, H. Mannen, M. Kobayashi, Y. Tanabe, A. Ogino and S. Tsuji. 2004. Genotype of stearoyl-coA desaturase is associated with fatty acid composition in JB cattle. Mamm. Genome 15:142-148.

Yin, D., S. D. Clarke, J. L. Peters and T. D. Etherton. 1998. Somatotropin-dependent decrease in fatty acid synthase mRNA abundance in 3T3-F442A adipocytes is the result of a decrease in both gene transcription and mRNA stability. Biochem. J. 331(Pt 3):815-820. 